\title{
Critical thinking in physics: Momentum critical thinking test for pre- service teacher
}

\author{
Ridho Adi Negoro ${ }^{1}$, Ani Rusilowati ${ }^{2 *}$, Mahardika Prasetya Aji ${ }^{3}$, Rosly Jaafar ${ }^{4}$ \\ 1, 2, 3 Physics Education Department, Universitas Negeri Semarang, Indonesia \\ ${ }^{4}$ Department of Physics, Universiti Pendidikan Sultan Idris, Malaysia \\ *Corresponding Address: rusilowati@yahoo.com
}

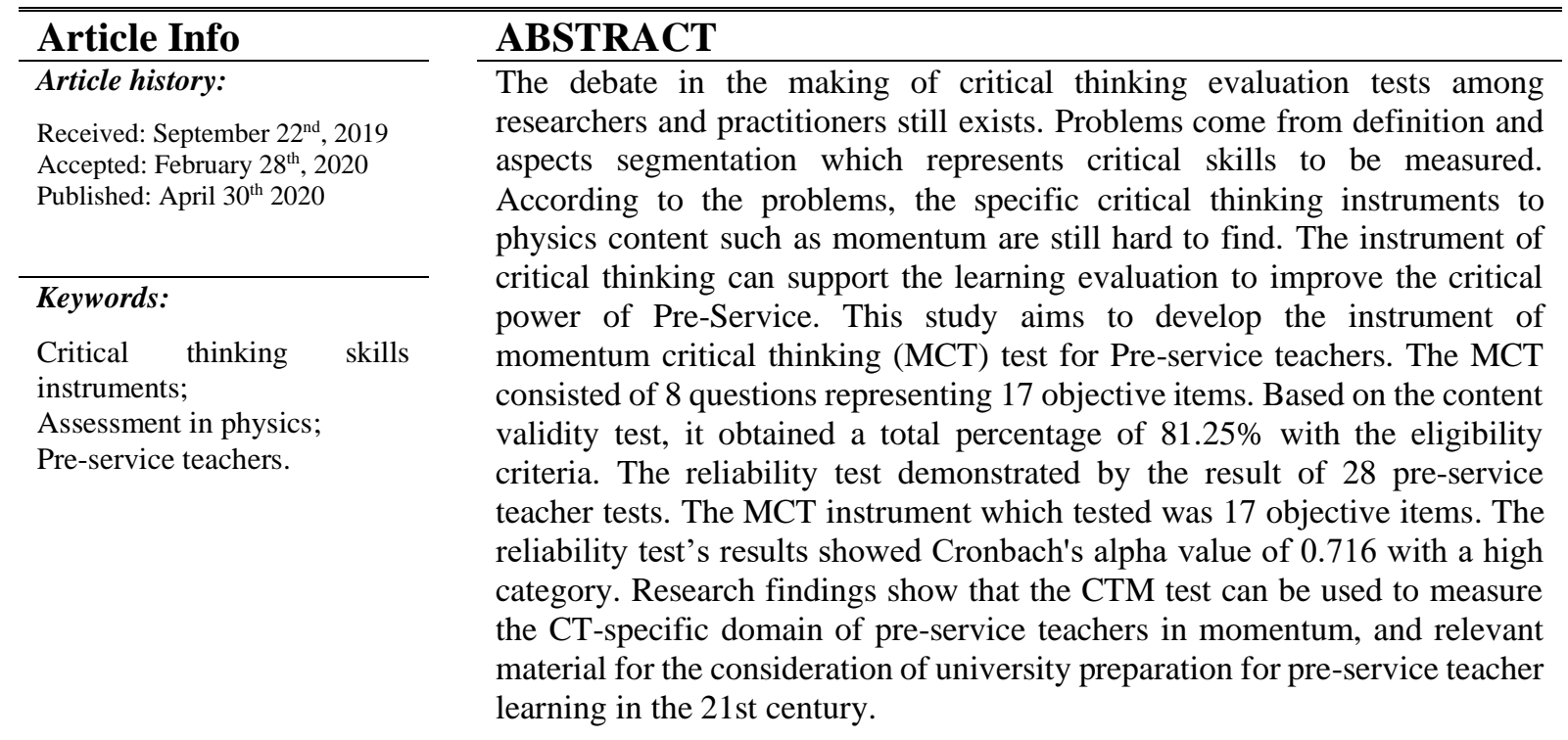

(C) 2020 Physics Education Department, UIN Raden Intan Lampung, Indonesia.

\section{INTRODUCTION}

Critical thinking is considered as one of the main skills needed by tertiary education graduates to face global change in the 21st century (Agustini \& Suyatna, 2018; Ayuningtias et al., 2018; Halpern, 2014; Rosefsky, 2012). The ideal critical thinker can evaluate the strength of the argument, gather relevant information and draw wellreasoned conclusions, make the right decision with various considerations, examine assumptions in-depth, evaluate the credibility of the source, and communicate effectively with others (Halpern, 2014). The education must be able to produce graduates with critical thinking skills because people assume that critical thinking can be learned in formal education or an academic environment. So that university education and scholars must find and explore appropriate learning to build critical thinking skills (Halpern, 2014; Kristoffer, 2017).

At present, there are high school students graduate with less critical thinking skills (Carlgren, 2013; Irwanto et al., 2018; Yamanaka et al., 2018). This problem comes from several factors. One of the main factors is teaching and learning which are complex and requires more attention, energy, and time (Greenstein, 2012; Rosefsky, 2012; Stobaugh, 2013; Yamanaka et al., 2018). In the end, teachers are required to have critical thinking skills so that the understanding of material content is clear (Janssen et al., 2019; 
Rosefsky, 2012; Utriainen et al., 2016). This demand is relevant to the teachers' professionalism by the needs of teachers for the development of human civilization in modern times.

Besides, high school teachers are now able to reach new generations of students in the 21 st century (Dyer \& Hall, 2019; Janssen et al., 2019; Richardson, 2011; Tang, 2018; Verburgh, 2019; Zhang \& Kim, 2018). This teacher will contribute directly to establish the experiences, ideology, pedagogy, and values that students need after graduation (Carlgren, 2013; Janssen et al., 2019). One way to solve secondary education problems is by preparing pre-service teachers. The efforts to prepare pre-service teachers in higher education are from teaching them to use critical thinking skills learning methods (Carlgren, 2013; Crenshaw et al., 2011; Dyer \& Hall, 2019; Fern et al., 2019; Sherblom, 2010). Universities must fight for, so that pre-service teachers can own and use critical thinking (Crenshaw et al., 2011; Dobozy, 2012; Shavelson et al., 2019).

Researchers and educators generally agree on the importance of teaching critical thinking skills in higher education (Dyer \& Hall, 2019; Tang, 2018). However, they argue about how to improve critical thinking skills through learning (Fern et al., 2019; Verburgh, 2019; Zhang \& Kim, 2018). Findings of learning to build critical thinking skills that were effective remain inconclusive. For example, some empirical studies use the same type of instructional learning but the results show with a different statistical picture (Chou et al., 2018; Kola et al., 2019; Morris et al., 2019). So the evaluation cycle is needed to analyze the constructs or aspects of thinking skills that need to make effective learning.

As the emphasis on developing critical thinking skills, the need for assessment becomes more important (Halpern, 2014; Lin, 2014). However, at the same time, the idea of critical thinking is debated on the continuous assessment process. The lack of a coherent and defensible concept of critical thinking has become a major problem. Disagreement exists between educators and researchers regarding the definition of Critical Thinking and what must be achieved in assessing Critical Thinking (Halpern, 2014).

One of the difficulties of the concept of critical thinking is the relationship between performance on the general domain and specific domain critical thinking tests is unclear. Recently, many types of research focused on developing a general critical thinking scale, but lack of developing specific domain measurements of critical thinking (Sustekova, 2019; Yu, 2017). Some experts argue that the general domain critical thinking skills test can measure the extent which students undertake a series of mental procedures, but they are not enough to ensure the critical thinking skills themselves (Tiruneh et al., 2017; Tiruneh et al., 2016).

Many critical thinking tests are arranged in a multiple-choice format (Bensley et al., 2016; Morris et al., 2018; Walsh et al., 2019). This aimed to reduce the bias that can appear in the answers. However, multiple-choice tests are weak to illustrate the originality of critical thinking (Greenstein, 2012; Stobaugh, 2013). Essay tests are more relevant to uncover a variety of thinking strategies used by thinkers and desired to learn outcomes (Franco et al., 2018; Sustekova, 2019; Tiruneh et al., 2016). Essay tests allow for open-ended cases and require thinkers (pre-service teachers) to compose a more straight forward description of arguments, reasons, predictive ideas.

Almost all physics learning content involves critical thinking skills. However, the availability of measuring instruments for critical thinking skills is still rare and limited to certain content. Some measurement instruments think critically based on content that is considered to have high abstractions such as electrodynamics (Tiruneh et al., 2017). This difficult material is proven by many cases of misconceptions of students and pre-service. After further exploration, there are still many pre-service teachers who 
have misconceptions besides electrodynamics, one of which is on the material of momentum (Bryce \& Macmillan, 2009; Kumar et al., 2016; Tiruneh \& Cock, 2018).

Students who can solve mathematical problems have an inadequate understanding of basic concepts and the inability to solve conceptual problems that are qualitative (Dega, 2019). This confirms that although students can manipulate complex mathematical equations and can master their operations, many of them do not understand fundamental conceptual principles. It was found that students had considerable misconceptions about the basic concepts of energy and momentum and their application and implications for everyday situations (Dega, 2019; Dega \& Govender, 2016). For example, previous research shows that there are problems with students' understanding of the concept of momentum. Many students do not realize that the momentum of an object at a particular time depends only on mass and speed and not on acceleration, and there are still many misunderstandings regarding the consequences of the law of conservation of energy and momentum towards the value of the coefficient of restitution (Dega, 2019; Dega \& Govender, 2016; Diyanahesa et al., 2017).

Based on the explanation above, the need for a measuring instrument in the form of a test for material momentum is important. This measuring instrument serves to uncover the critical thinking skills of pre-service teachers who are required to be able to teach critical thinking skills. Many critical thinking tests only evaluate general critical thinking skills (Bassett, 2016; Sustekova, 2019; Yu, 2017). Many studies have concluded that critical thinking has a specification of the subject or specification of the domain so that evaluation of critical thinking ability is required to have specification according to their fields (Tiruneh et al., 2017; Yu, 2017).

This study aims to develop a Momentum Critical Thinking (MCT) test. The general domain of critical thinking skills that become a criterion for adaptation in the development of the MCT test is Hypothesis testing, Argument Analysis, Reasoning, likelihood and uncertainty analysis, Problem-solving and decision-making (Halpern, 2014). The specific domain MCT test adapted from the CTEM test by Tiruneh et al (2016) and was developed into several concrete indicators for the essay test. The specific domains are arranged to make the test authentic and following the area in which they are involved (Tiruneh et al., 2016; Yu, 2017). MCT is oriented to the real phenomena of life with content related to material momentum.

\section{METHODS}

This research was categorized as educational development research or commonly abbreviated as R\&D. Momentum Critical Thinking Test (MCT) for PreService teachers was a product developed in this study. This research was conducted from May $13^{\text {th }}, 2019$ to August $9^{\text {th }}, 2019$.

At the beginning of the activity, a potential and problem analysis is carried out in pre-service teacher's critical analysis of momentum which often appears. The data obtained were analyzed and used as a reference to make a critical thinking test design of the momentum material. The product in this study is the MCT test for PreService Teachers which will be used to analyze and evaluate the critical thinking skills of Pre-Service Teachers. MCT test has the form of a description test consisting of 4 themes. Theme 1 contains the law of conservation of momentum on impact. Theme 2 contains experimental content determining the coefficient of restitution through the reflection of a dropped ball. Theme 3 contains predictive content and opportunities for the collision of an object. Theme 4 contains content on life-related problems that must be solved with solutions from pre-service teachers. Theme 1 consists of 3 questions, theme 2 consists of 1 questions, theme 3 consists of 2 questions, and theme 4 consists of 2 questions. All themes raise contradictory content, each 
theme is described by different phenomena. Research and development of Momentum Critical Thinking (MCT) test for Pre-Service Teachers consist of 6 stages which are adapted from 10 stages of research from Borg and Gall (Anderson et al., 2018) as Figure 1.

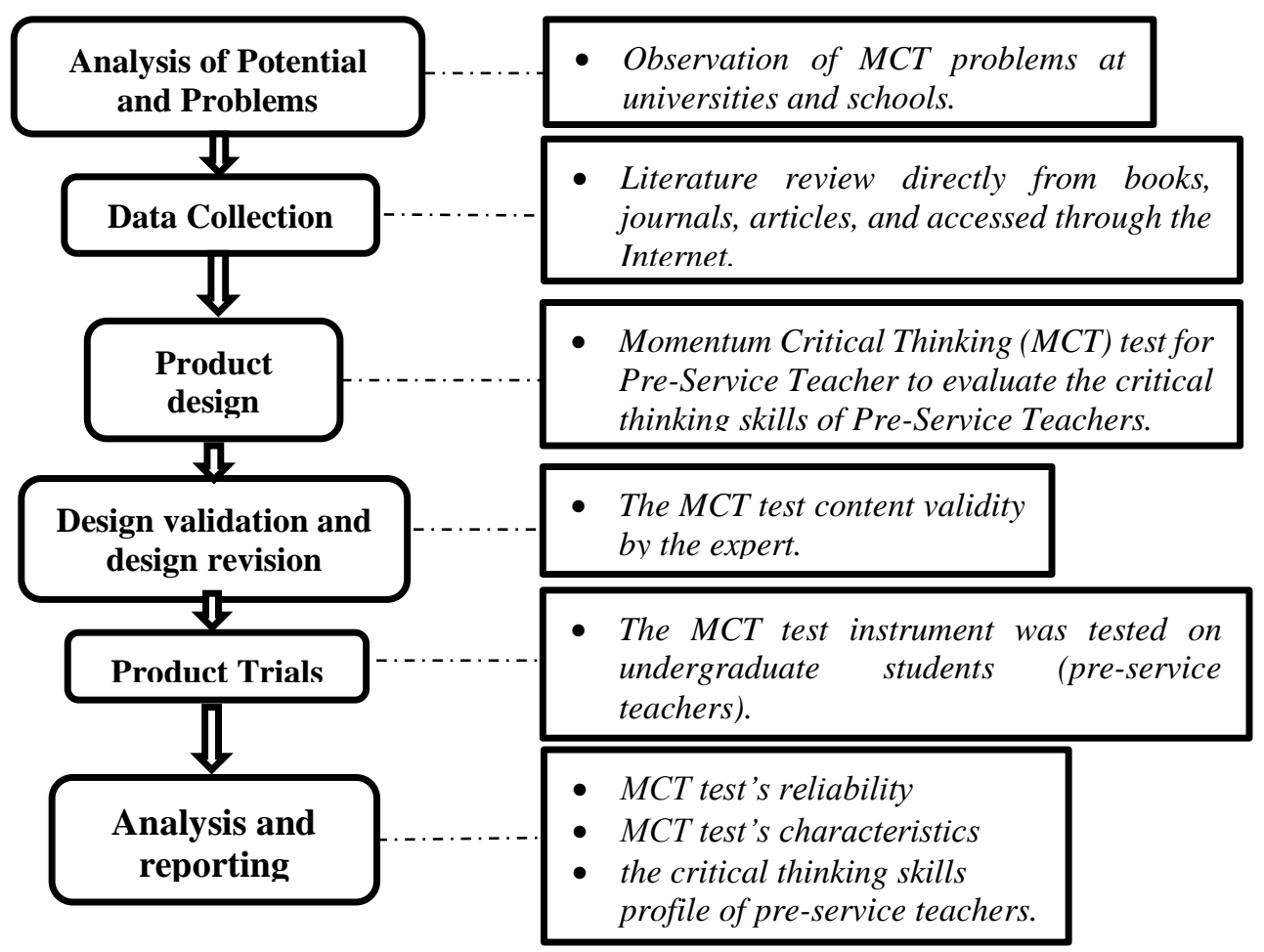

Figure 1. Momentum Critical Thinking Test Production Steps

Before being tested, the test instrument is going through the feasibility test by evaluating its feasibility through expert judgment. This feasibility assessment is to determine the validity of the content in terms of material aspects, the completeness of the content, the suitability of the test items to the aspects, the strength of the instrument to reveal critical thinking skills.

The results of the feasibility test through expert judgment were analyzed using the formula (Negoro et al., 2017).

$$
P=\frac{f}{N} x 100 \%
$$

Where:

$\boldsymbol{P}$ : percentage rating

$f$ : score obtained

$N$ : overall score
Table 1. Feasibility Criteria

\begin{tabular}{l|l}
\hline Percentage & Information \\
\hline $85 \%<$ value $\leq 100 \%$ & Very feasible \\
$70 \%<$ value $\leq 85 \%$ & Feasible \\
$50 \%<$ value $\leq 70 \%$ & Less feasible \\
$1 \%<$ value $\leq 50 \%$ & infeasible \\
\hline
\end{tabular}

In this study, a field trial was conducted at Semarang State University involving 6thsemester students, totaling 28 people. A trial was conducted to obtain the results of the test as an instrument of analysis in the form of characteristics, namely the level of difficulty, the distinguishing power of questions for each specific domain of critical thinking skills, and the pre-service teacher critical thinking skills profile. The reliability test of the breakdown test was carried out through analysis using the Cronbach Alpha formula. 


\section{RESULTS AND DISCUSSION}

The results of this study are the Momentum Critical Thinking (MCT) test instruments. This instrument has a strategic function for analyzing pre-service teacher thinking skills with momentum material content in the form of profiles. In the learning of momentum, there are cases of misconceptions that are still commonly found. MCT test with the function of revealing critical thinking skills allows the results obtained to be used as a reference for the analysis phenomenon skills of pre-service teachers. The ability of this analysis can show the principles or conceptual relationships that pre-service teachers believe.

\section{The Existing Potentials and Problems Found}

Potential based on needs analysis and observations show that there is still no test instrument that capable to express the critical thinking skills of pre-service teachers on the content of physics learning material momentum. Furthermore, Pre-service Physics Teachers are expected to possess and be able to apply critical thinking skills concerning learning material and after graduating pre-service teachers have competencies relevant to changing times. So, the MCT test is required as a tool to evaluate their Critical Thinking Skills.

\section{Collection of Information}

Information obtained from the literature is read directly from books, journals, articles, and accessed through the Internet. Also, information was collected through interviews with lecturers. Based on the results of information gathering, components that need to be developed in the MCT test instruments include relevant, rational, and consistent aspects of the test in expressing critical thinking skills of pre-service teachers. The relevant test is that the content raised has a relationship with real-life so that critical analysis of pre-service teachers is relevant to their lives. Rational test means the test has the power to uncover every aspect of critical thinking with a good logical comparison to translate. Whereas consistent tests are tests that reveal every aspect of focused thinking skills as minimization of bias.

\section{Product Design}

Based on the analysis of potentials, problems, and sources of informants, a Momentum Critical Thinking (MCT) test for Pre-Service Teacher will be developed to analyze and evaluate the critical thinking skills of Pre-Service Teachers. MCT test takes the form of a description test consisting of 4 themes. There are 8 questions on all available themes. Theme 1 consists of 3 questions, theme 2 consists of 1 questions, theme 3 consists of 2 questions, and theme 4 consists of 2 questions. Each question includes several objective items counting from 20 items derived from. Each theme can have more than one general domain of critical thinking which is revealed to be specific. The specific domain of critical thinking skills revealed through the MCT test adapted from CTEM (Tiruneh et al., 2016). Aspects of critical thinking on the MCT test are relevant to critical thinking skills with the content of science material. MCT test raised the content of momentum material that was still too mathematical and had difficult concepts to be taught. A phenomenon related to momentum is very tight in daily life, but there are still many pre-service teachers who experience misconceptions (Triyani et al., 2019; Kumar et al., 2016). One of the most influential factors is the mathematical formulation that is too dominant in learning. MCT test seeks to uncover critical power in pre-service teacher thinking, how they analyze the phenomenon of momentum in life as well as having mastered the mathematical formulation or equation. MCT test aspects of critical thinking skills are specified as an indicator for the assessment test description in Table 2. 
Table 2. Aspects of Critical Thinking Skills

\begin{tabular}{|c|c|c|}
\hline CT Aspects & Specific Domain in Science & MCT Specific Domain \\
\hline \multirow[t]{3}{*}{$\begin{array}{l}\text { Hypothesis } \\
\text { testing }\end{array}$} & $\begin{array}{l}\text { - Interpret the relationship } \\
\text { between variables }\end{array}$ & $\begin{array}{l}\text { Show the relationship between variables in the } \\
\text { momentum phenomenon }\end{array}$ \\
\hline & $\begin{array}{l}\text { - Recognize the need for more } \\
\text { information in drawing } \\
\text { conclusions }\end{array}$ & $\begin{array}{l}\text { Show the lack/adequacy of information in the } \\
\text { form of mathematical or logical linkages } \\
\text { between variables }\end{array}$ \\
\hline & $\begin{array}{l}\text { - Identify when the principle of } \\
\text { causality can and cannot be } \\
\text { made }\end{array}$ & $\begin{array}{l}\text { Show the cause and effect by looking at the } \\
\text { effect of the type of material on the type of } \\
\text { collision appropriately. }\end{array}$ \\
\hline \multirow[t]{2}{*}{$\begin{array}{l}\text { Argument } \\
\text { Analysis }\end{array}$} & $\begin{array}{l}\text { - Identify important parts of an } \\
\text { argument }\end{array}$ & $\begin{array}{l}\text { Show the cause and effect by looking at the } \\
\text { effect of the type of material on the type of } \\
\text { collision appropriately. }\end{array}$ \\
\hline & $\begin{array}{l}\text { - Criticize the validity of } \\
\text { generalizations in experiments }\end{array}$ & $\begin{array}{l}\text { Show the lack/adequacy of analysis/data from } \\
\text { some of the induction arguments } \\
\text { (generalizations) appropriately }\end{array}$ \\
\hline \multirow[t]{2}{*}{ Reasoning } & - Evaluate validity data & $\begin{array}{l}\text { Show the relationship/trends between } \\
\text { experimental data, the suitability between data } \\
\text { and then concluded correctly. }\end{array}$ \\
\hline & - Detects ambiguity & $\begin{array}{l}\text { Answer by indicating an error in the data and } \\
\text { its cause. }\end{array}$ \\
\hline \multirow{2}{*}{$\begin{array}{l}\text { Likelihood } \\
\text { and } \\
\text { uncertainty } \\
\text { analysis }\end{array}$} & $\begin{array}{l}\text { - Predict the probability of an } \\
\text { event }\end{array}$ & $\begin{array}{l}\text { Show consideration of the most likely event } \\
\text { based on the consideration of the factors } \\
\text { affected }\end{array}$ \\
\hline & $\begin{array}{l}\text { - Understand the need for } \\
\text { additional information in } \\
\text { making decisions }\end{array}$ & $\begin{array}{l}\text { Show consideration of other influences that are } \\
\text { not narrated in phenomena }\end{array}$ \\
\hline \multirow[t]{2}{*}{$\begin{array}{l}\text { Problem- } \\
\text { solving and } \\
\text { decision- } \\
\text { making }\end{array}$} & $\begin{array}{l}\text { - Identify the best decision } \\
\text { among several alternatives in } \\
\text { solving problems }\end{array}$ & $>$ Show some alternative rational solutions \\
\hline & $\begin{array}{l}\text { - evaluating solutions to } \\
\text { problems and making strong } \\
\text { decisions }\end{array}$ & $\begin{array}{l}\text { Show and classify several alternative solutions } \\
\text { with rational considerations to do }\end{array}$ \\
\hline
\end{tabular}

\section{Product Validation}

After the initial product is complete, the next step is to test the content validity by the expert. Material experts check the test instrument criteria including (a) the suitability of the items with the test objectives and test-taker population, (b) the accuracy of the information presented in the items, and (c) the clarity of words/phrases/diagrams of each item. Based on the material feasibility test questionnaire obtained a total percentage of $81.25 \%$ with the eligibility criteria.

\section{Trial Results}

The MCT test instrument was tested on 28 undergraduate students. Based on the trial results, it can be described as the results in the form of instrument reliability, instrument characteristics, and the critical thinking skills profile of pre-service teachers.

\section{Characteristics of the MCT test}

The characteristics of the MCT test are described through the level of difficulty of the questions and the different forces listed in Table 3. MCT test has 8 questions with 17 objective items used with the detected difficulty level of 10 easy items, 4 medium 
items, and 3 difficult items. Test reliability is demonstrated by the results of 28 pre-service teacher tests. The MCT test instrument that was tested consisted of 17 item objectives. The reliability results showed by Cronbach's alpha value of 0.716 with a high category.

Theme 1 of the MCT test is shown in Figure 2. It has several questions to uncover some general domains of critical thinking. Question number one reveals general domain Hypothesis testing with specific domains interpreting relationships between variables and recognizing the need for more information in concluding. Specific domain achievement of interpreting the relationships between variables is illustrated by indicators of student answers that are showing the relationship between momentum, mass, and speed as well as the influence of air resistance. The specific-domain achievement of recognizing the need for more information in concluding is illustrated by indicators of student responses that show a mathematical or logical connection between momentum and mass and velocity precisely.

\section{Critical Thinking Skills Pre-Service} Teachers

The aspects of Hypothesis testing, Argument Analysis, likelihood and uncertainty analysis in the instrument are built by considering the interrelated process of variable analysis skills in a momentum phenomenon. Hypothesis testing, Reasoning, and Problem-solving and decision-making aspects are explored by providing problems related to the phenomena that have been made after that the pre-service teacher analyzes by compiling essays or descriptions.

Tabel 3. Level of Difficulty and Discrimination Power

\begin{tabular}{cccc}
\hline $\begin{array}{c}\text { Item } \\
\text { Objectives }\end{array}$ & DP & LD & Interpretation \\
\hline 1 & 0.43 & $0.82^{\text {a) }}$ & Item Received \\
2 & 0.44 & $0.80^{\text {a) }}$ & Item Received \\
3 & 0.57 & $0.71^{\text {a) }}$ & Item Received \\
4 & 0.69 & $0.70^{\text {b) }}$ & Item Received \\
5 & 0.55 & $0.66^{\text {b) }}$ & Item Received \\
$6^{*}$ & 0.15 & $0.43^{\text {a) }}$ & Item Rejected \\
7 & 0.59 & $0.26^{\text {c) }}$ & Item Received \\
8 & 0.45 & $0.29^{\text {c) }}$ & Item Received \\
9 & 0.44 & $0.89^{\text {a) }}$ & Item Received \\
10 & 0.61 & $0.86^{\text {a) }}$ & Item Received \\
11 & 0.63 & $0.71^{\text {a) }}$ & Item Received \\
12 & 0.47 & $0.54^{\text {b) }}$ & Item Received \\
$13^{*}$ & 0.18 & $0.63^{\text {b) }}$ & Item Rejected \\
14 & 0.66 & $0.89^{\text {a) }}$ & Item Received \\
15 & 0.42 & $0.24^{\text {c) }}$ & Item Received \\
16 & 0.41 & $0.75^{\text {a) }}$ & Item Received \\
17 & 0.52 & $0.71^{\text {a) }}$ & Item Received \\
18 & 0.43 & $0.68^{\text {b) }}$ & Item Received \\
19 & 0.46 & $0.79^{\text {a) }}$ & Item Received \\
$20^{*}$ & 0.19 & $0.54^{\text {b) }}$ & Item Rejected \\
\hline Easy $^{\text {a) }}$ Medium ${ }^{\text {a) }}$ Difficult & &
\end{tabular}




\section{Theme 1}
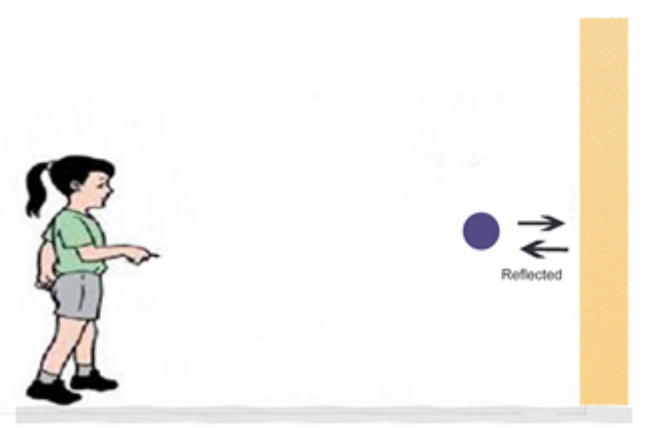

Hanna throws 2 balls made of Iron and Plastic (Both balls have the same mass). Hanna throws both of them towards the wall at a speed high enough that the two balls almost move perfectly straight. When hitting a wall, an iron ball bounces with a lower speed than a plastic ball.

Question :

1. From the events above, which ball has greater momentum before the collision? Explain in detail!

2. From the reflections of the ball that occur iron experiences shorter reflections / lower speed, why does this happen? Explain in detail!

3. Two of Hanna's friends, Anto and Dilan, watch the ball that Hanna throws. Anto considers that the iron ball bounces at a slower speed due to different types of mashing material. Meanwhile, according to Dilan, the lower iron momentum before collision results in the reflection of iron having a lower speed. What do you think caused the two of them to think differently? Then who is right? Explain in detaill!

Figure 2. Theme 1 of the MCT test

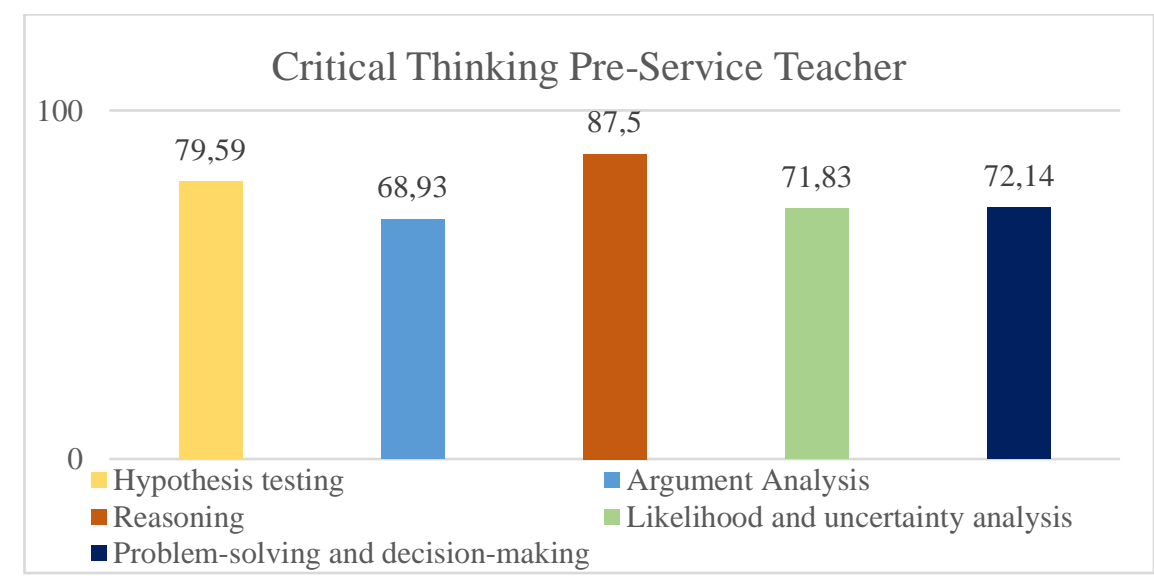

Figure 3. Achievement of Critical Thinking Skills in Pre-Service Teachers

Based on the results in Figure 3, some aspects have the lowest achievement compared to the others, namely the aspect of argument analysis. This is because of the lack of views on the construction of the arguments compiled in the test. Most of the answers prepared by the pre-service teacher do not indicate the lack or adequacy of the analysis 
and data from some of the induction arguments used as generalizations of phenomena. Besides, Pre-Service Teacher shows the variables that become the second reference arguments exactly. Description of Preservice Teacher's answers to question 3 in theme 1 can be seen in Table 4.

Table 4. Question and Answer of Phenomenon and Argument Analysis Aspect Questions

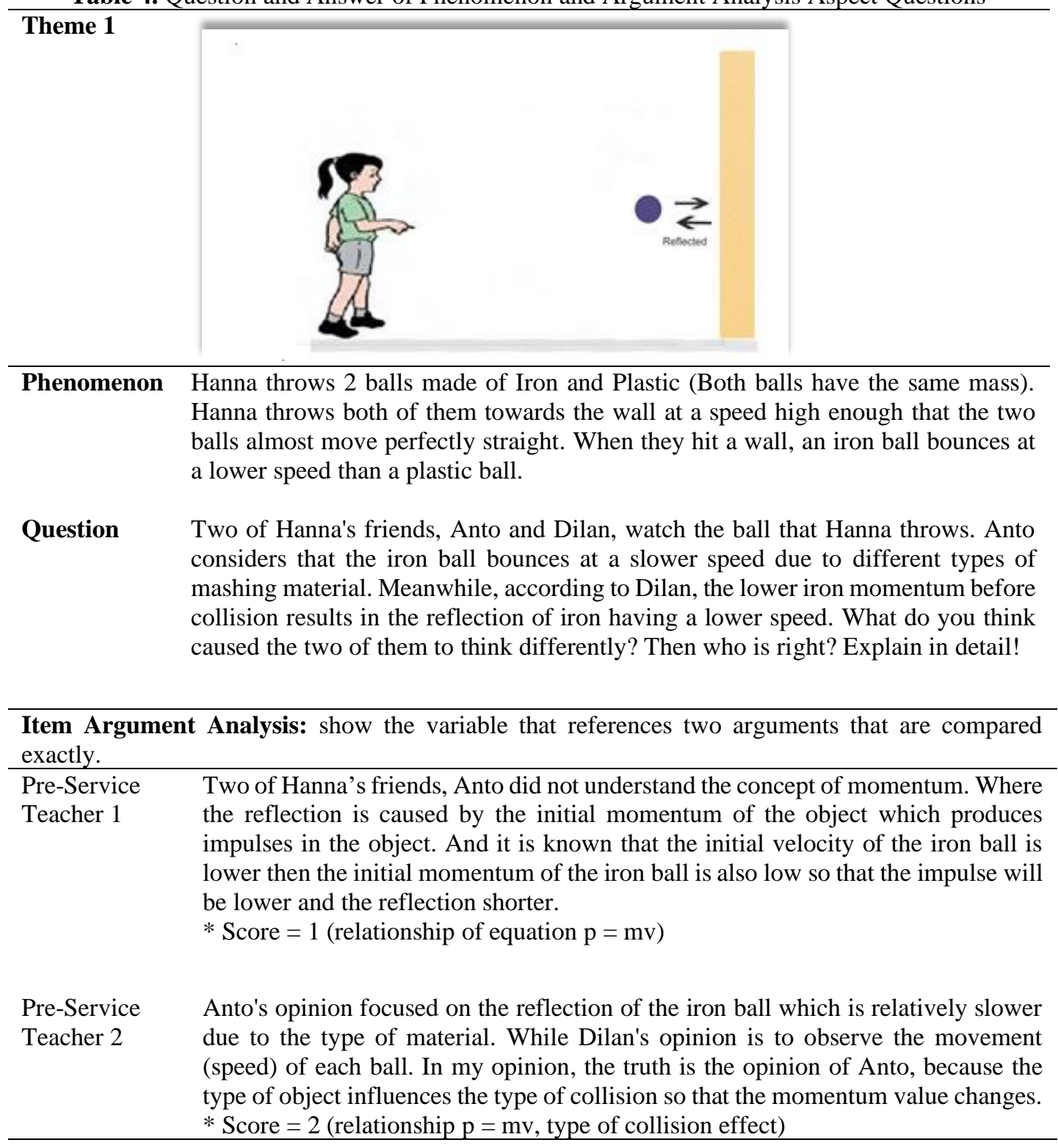

The development of critical thinking skills test is very important in the specific domain of physics, researchers and practitioners need to test the validity and relevant judgment. Based on the results of the validation, the specific domain design of the MCT test has good relevance to the momentum material. Overall data analysis shows that the MCT test is sufficient to be tested and a good basis for measuring critical thinking skills in momentum with good relevance specific domain. The results are following the findings in the field that identification in detail and concrete-related aspects of critical thinking can support the improvement of students' mastery of concept (Tiruneh et al., 2017). Material experts are involved during the item development stage to review the depth of each item. Interviews were also conducted with pre-service teachers who 
conducted the tests so that the MCT test had evidence that the items were focused and on target in exploring critical thinking skills. Although this test is relatively difficult, it still shows enough different power for each item. This is indicated by the different power indexes and the level of difficulty of the questions.

Many critical thinking tests are made in a multiple-choice format, for example, the California Critical Thinking Skills Test, ACT Collegiate Assessment, Halpern Critical Thinking Assessment. This aims to reduce the bias of participants' answers so that they are controlled in their assessment (Bassett, 2016; Shavelson et al., 2019). However, the originality of the participants' critical thinking will not come out, because the answers have been controlled (Aloisi \& Callaghan, 2018; Bassett, 2016). MCT test in essay format reveals the originality of participants' critical thinking by considering answer bias through domain-specific design and comprehensive indicators.

We can underline that MCT is designed to have a strong and relevant specific domain. This is done because of many research lack of developing specific-domain measurement of critical thinking (Sustekova, 2019; Yu, 2017). Also, the MCT test in the essay format considers the bias avoided by multiplechoice tests through detailed answer indicators. MCT also tries to make efficient tests through the design of a single question revealing more than one specific domain.

Our next hope is that MCT tests can be used as instruments for research purposes. MCT test has a basis to be used to answer the research questions needed for momentum material. Although it can be recognized that the validation procedure described in this study is still in the form of an initial effort, we hope this effort has an approach that can be used as a reference to develop and validate tests of critical thinking skills in other science content.

\section{CONCLUSION}

Based on the results of research and discussion, it can be concluded that the product developed is valid as a Critical Thinking Test for Pre-Service Teachers. This is shown from the results of the content validity test obtained with a total percentage of $81.25 \%$ with the eligibility criteria. Test reliability is demonstrated by the results of 28 pre-service teacher tests. The MCT test instruments tested consisted of 17 objective items showing the Cronbach alpha value as an interpretation of the test reliability of 0.716 with a high category.

\section{ACKNOWLEDGMENT}

The researchers highly appreciate material experts for constructive suggestions and feedback on developing critical thinking instruments for momentum material for PreService Teachers.

\section{AUTHOR CONTRIBUTIONS}

RA conceptualization and reviewing literature, AR, MP, RJ develop product. MP collected and analysed data. RJ display design. All authors contributed to the writing of manuscript.

\section{REFERENCES}

Agustini, R., \& Suyatna, A. (2018). Developing inquiry-based practice equipment of heat conductivity to foster the students' critical thinking ability, 07(1), 49-57. https://doi.org/10.24042/jipfalbiruni.v7 i1.1848

Aloisi, C., \& Callaghan, A. (2018). Threats to the validity of the collegiate learning assessment ( CLA + ) as a measure of critical thinking skills and implications for learning gain. Higher Education Pedagogies, 3(1), 137-162. https://doi.org/10.1080/23752696.2018. 1449128

Anderson, R. G., Knobloch, N., Lambert, M., Saucier, R., Christiansen, J., Dibenedetto, C. A., ... Wang, H. (2018). Instrument validity in manuscripts. 
Journal of Agricultural Education, 59(3).

Ayuningtias, M. D., Suyatna, A., Suyanto, E., \& Nwineh, L. (2018). development of lcds-based interactive electronic school book on blackbody radiation as self-instructional materials for fostering student's critical thinking, 07(October), 183-193.

https://doi.org/10.24042/jipfalbiruni.v7 i2.2518

Bassett, M. H. (2016). Teaching critical thinking without (much) writing: Multiple-choice and metacognition, 19(1), 20-40.

Bensley, D. A., Rainey, C., Murtagh, M. P., Flinn, J. A., Maschiocchi, C., Bernhardt, P. C., \& Kuehne, S. (2016). Closing the assessment loop on critical thinking: The challenges of multidimensional testing and low test-taking motivation. Thinking Skills and Creativity, 21, 158168.

https://doi.org/10.1016/j.tsc.2016.06.00 6

Borg, W. R., \& Gall, M. D. (2007). Educational research: An introduction. London: Longman.

Bryce, T. G. K., \& Macmillan, K. (2009). Momentum and kinetic energy: Confusable concepts in secondary school physics, 46(7), 739-761. https://doi.org/10.1002/tea.20274

Carlgren, T. (2013). Communication, critical thinking, problem solving: a suggested course for all high school students. Interchange, 44, 63-81. https://doi.org/10.1007/s10780-0139197-8

Chou, T., Wu, J., \& Tsai, C. (2018). Research trends and features of critical thinking studies in e-learning environments: A review. Journal of Educational Computing Research,. https://doi.org/10.1177/0735633118774 350

Crenshaw, P., Hale, E., \& Harper, S. L. (2011). Producing intellectual labor in the classroom: The utilization of a critical. Journal of College Teaching \& Learning, 8(7), 13-26. https://doi.org/https://doi.org/10.19030/ tlc.v8i7.4848

Dega, B. G. (2019). Cognitive diagnostic assessment of students responses: An example from energy and momentum concepts. European Journal of Physics Education, 10(1), 13-23.

Dega, B. G., \& Govender, N. (2016). Assessment of students' scientific and alternative conceptions of energy and momentum using concentration analysis assessment of students' scienti fi c and alternative. African Journal of Research in Mathematics, Science and Technology Education, 20(3), 1-13. https://doi.org/10.1080/18117295.2016. 1218657

Diyanahesa, N. E.-H., Kusairi, S., \& Latifah, E. (2017). Development of misconception diagnostic test in momentum and impulse using isomorphic problem. Journal of Physics: Theories and Applications, 1(2), 145-156.

Dobozy, E. (2012). Failed innovation implementation in teacher education: A case analysis. Problems of Education in the 21st Century, 40, 35-44.

Dyer, K. D., \& Hall, R. E. (2019). Effect of critical thinking education on epistemically unwarranted beliefs in college students. Research in Higher Education, 60(3), 293-314. https://doi.org/10.1007/s11162-0189513-3

Ennis, R. H., \& Millman, J. (2005). Cornell critical thinking test: Level Z, Seaside, CA: The Critical Thinking Co. formerly Midwest Publications.

Fern, D., Poblete, M., \& Galindo-dom, H. (2019). Methodologies for teachinglearning critical thinking in higher education: The teacher's view. Thinking Skills and Creativity, 33. https://doi.org/10.1016/j.tsc.2019.1005 84

Franco, A. R., Costa, P. S., \& Almeida, S. 
(2018). Translation, adaptation, and validation of the halpern critical thinking assessment to portugal: Effect of disciplinary area and academic level on critical thinking. Annals of Psychology, 34(2), 292-298.

Greenstein, L. M. (2012). Assessing 21st century skills: A guide to evaluating mastery and authentic learning. California: Corwin Press.

Halpern, D. F. (2014). Critical thinking across the curriculum: A brief edition of thought \& knowledge (5th ed.). New York: Routledge.

Irwanto, I., Rohaeti, E., \& Prodjosantoso, A. K. (2018). A survey analysis of preservice chemistry teachers' critical thinking skills. Journal of Educational Studies, Trends and Practices, 8(1), 5773.

Janssen, E. M., Meulendijks, W., Mainhard, T., Verkoeijen, P. P. J. L., Heijltjes, A. E. G., Peppen, L. M. Van, \& Gog, T. Van. (2019). Identifying characteristics associated with higher education teachers' cognitive reflection test performance and their attitudes towards teaching critical thinking. Teaching and Teacher Education, 84, 139-149. https://doi.org/10.1016/j.tate.2019.05.0 08

Kola, M., Rauscher, W., \& Haupt, G. (2019). Grade 9 technology teachers' explication of critical thinking and its enactment in the classroom grade 9 technology teachers' explication of critical. African Journal of Research in Mathematics, Science and Technology Education, $\quad 0(0), \quad 1-12$. https://doi.org/10.1080/18117295.2019. 1601457

Kristoffer, L. (2017). Understanding and teaching critical thinking - A new approach, 84(May), 32-42. https://doi.org/10.1016/j.ijer.2017.05.0 04

Kumar, R., Zhi-gang, Z., \& Livadiotis, G. (2016). The learning reconstruction of particle system and linear momentum conservation in introductory physics course the learning reconstruction of particle system and linear momentum conservation in introductory physics course. Journal of Physics: Conference Series, 739. https://doi.org/10.1088/17426596/739/1/012111

Lin, S. (2014). Science and non-science undergraduate students, critical thinking and argumentation performance in reading a science news report. International Journal of Science and Mathematics Education, 12(5), 1023-1045.

Morris, R. J., Brockner, A. E., Coleman, S. E., \& Morris, R. J. (n.d.). Effectiveness of two methods for teaching critical thinking to communication sciences and disorders undergraduates. Canadian Journal of Speech-Language Pathology \& Audiology, 43(1).

Morris, R. J., Gorham-rowan, M. M., Robinson, J. H., Morris, R. J., \& Scholz, K. (2018). Assessing and teaching critical thinking in communication science and disorders assessing and teaching critical hinking in communication science and disorders. Teaching and Learning in Communication Science \& Disorders, 2(1).

Negoro, R. A., Susanto, H., \& Rusilowati, A. (2017). Pengembangan media pembelajaran fotonovela berbantuan audio materi bunyi untuk siswa tunarungu SMP LB/MTs LB. Unnes Physics Education Journal, 6(2).

Richardson, J. (2011). Tune in to what the new generation of teachers. Phi Delta Kappan, 92(8), 1-6. https://doi.org/https://doi.org/10.1177/0 03172171109200804

Rosefsky, A. (2012). Learning 21st century skills requires 21 st century teaching. Phi Delta Kappan, 94(2), 8-10.

Shavelson, R. J., Zlatkin-troitschanskaia, O., Beck, K., \& Marino, J. P. (2019). Assessment of university students' 
critical thinking: next generation performance assessment assessment of university students' critical thinking: next generation performance assessment. International Journal of Testing, $\quad 0(0), \quad 1-20$. https://doi.org/10.1080/15305058.2018. 1543309

Sherblom, P. (2010). Creating critically thinking educational leaders with courage, knowledge and skills to lead tomorrow's schools today. Journal of Practical Leadership, 5(1), 81-90.

Snyder, S. J., Edwards, L. C., \& Sanders, A. L. (2019). An empirical model for infusing critical thinking into higher education. Journal on Excellence in College Teaching, 30, 127-156.

Stobaugh, R. (2013). Assessing critical thinking in middle and high schools: Meeting the Common Core. New York: Routledge.

Sustekova, E. (2019). Validation of critical thinking test on slovak conditions. EURASIA Journal of Mathematics, Science and Technology Education, 15(12).

Tang, K. N. (2018). The importance of soft skills acquisition by teachers in higher education institutions. Kasetsart Journal of Social Sciences, 2-7. https://doi.org/10.1016/j.kjss.2018.01.0 02

Tiruneh, D. T., \& Cock, M. De. (2018). Designing learning environments for critical thinking: Examining effective instructional approaches, 1065-1089. https://doi.org/10.1007/s10763-0179829-Z

Tiruneh, D. T., De Cock, M., Weldeslassie, A. G., Elen, J., \& Janssen, R. (2017). Measuring critical thinking in physics: Development and validation of a critical thinking test in electricity and magnetism. International Journal of Science and Mathematics Education, 15(4), 663-682. https://doi.org/10.1007/s10763-0169723-0
Tiruneh, D. T., Weldeslassie, A. G., Kassa, A., Tefera, Z., Cock, M., \& Elen, J. (2016). specific and domain-general critical thinking skills. Educational Technology Research and Development, 64(3), 481-505. https://doi.org/10.1007/s11423-0159417-2

Triyani, G., Danawan, A., Suyana, I., \& Kaniawati, I. (2019). An investigation of students misconceptions about momentum and impulse through interactive conceptual Instruction (ICI) with computer simulation. In Journal of Physics: Conference Series (Vol. 1280, p. 52008).

Utriainen, J., Marttunen, M., Kallio, E., \& Tynjälä, P. (2016). University applicants' critical thinking skills : the case of the finnish educational sciences university applicants' critical thinking skills: The case of the scandinavian Journal of Educational Research, 61(6), 629-649.

https://doi.org/10.1080/00313831.2016. 1173092

Verburgh, A. (2019). Studies in higher education effectiveness of approaches to stimulate critical thinking in social work curricula. Studies in Higher Education, $\quad 0(0), \quad 1-12$. https://doi.org/10.1080/03075079.2019. 1586336

Walsh, C., Quinn, K. N., Wieman, C., \& Holmes, N. G. (2019). Quantifying critical thinking: Development and validation of the physics lab inventory of Critical thinking (PLIC), 1-16.

Yamanaka, S., Inoshita, H. K., \& Aehara, T. M. (2018). A Study on training of critical thinking attitude in high school chemistry through instruction focusing on argumentation. Japan Journal of Educational Technology, 33(4), 411422.

$\mathrm{Yu}$, K. (2017). The Development and validation of a mechanical critical thinking scale for high school students, 8223(5),

1361-1376. 
https://doi.org/10.12973/eurasia.2017.0 $0675 \mathrm{a}$

Zhang, L., \& Kim, S. (2018). Critical thinking cultivation in chinese college english classes. English Language Teaching, 11(8), 1-6. https://doi.org/10.5539/elt.v11n8p1.

Yerimadesi, Y., Bayharti, B., Azizah, A., Lufri, L., Andromeda, A., \& Guspatni, G. (2019). Effectiveness of acid-base modules based on guided discovery learning for increasing critical thinking skills and learning outcomes of senior high school student. Journal of Physics: Conference Series, 1185(1). https://doi.org/10.1088/1742-
6596/1185/1/012151

Yuliati, L., Fauziah, R., \& Hidayat, A. (2018). Student's critical thinking skills in authentic problem based learning. Journal of Physics: Conference Series, 1013(1). https://doi.org/10.1088/17426596/1013/1/012025

Zain, A. R., \& Jumadi. (2018). Effectiveness of guided inquiry based on blended learning in physics instruction to improve critical thinking skills of the senior high school student. Journal of Physics: Conference Series, 1097(1). https://doi.org/10.1088/1742-

6596/1097/1/012015 